\title{
Enzymatic saccharification of pretreated rice straw by cellulases from Aspergillus niger BK01
}

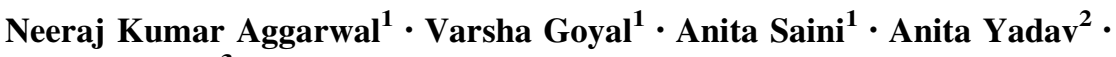 \\ Ranjan Gupta ${ }^{3}$
}

Received: 28 November 2016/Accepted: 30 January 2017/Published online: 16 June 2017

(C) Springer-Verlag Berlin Heidelberg 2017

\begin{abstract}
Alkali-assisted acid pretreated rice straw was saccharified using cellulase from Aspergillus niger BK01. The cellulase production by the fungus was enhanced by parametric optimization using solid-state fermentation conditions. Maximum cellulase production $(12.0 \mathrm{U} / \mathrm{gds}$ of carboxymethyl cellulase, CMCase) was achieved in $96 \mathrm{~h}$, using $6.0 \%$ substrate concentration, $7.5 \%$ inoculum concentration, 1:2 solid to liquid ratio, at $\mathrm{pH} 5.5$, and temperature $28{ }^{\circ} \mathrm{C}$, by supplementation of the fermentation medium with $0.1 \%$ carboxymethylcellulose and $0.1 \%$ ammonium nitrate. Characterization of crude cellulases showed that highest CMCase activity was observed at $\mathrm{pH}$ 4.8 and temperature $40{ }^{\circ} \mathrm{C}$. The CMCase was stable from $\mathrm{pH} 4.8-5.5$ and at a temperature range of $35-50{ }^{\circ} \mathrm{C}$. The pretreated biomass was subjected to hydrolysis with the fungal cellulases. The saccharification optimization studies showed that $2 \%(\mathrm{v} / \mathrm{v})$ enzyme concentration and hydrolysis time of $2.5 \mathrm{~h}$ were optimum for maximum yield, i.e, $23.78 \%$ sugars and $35.96 \%$ saccharification value.
\end{abstract}

Keywords Aspergillus niger · Cellulases · Optimization · Pretreated $\cdot$ Rice straw $\cdot$ Saccharification

Neeraj Kumar Aggarwal

neerajkuk26@rediffmail.com

1 Department of Microbiology, Kurukshetra University, Kurukshetra, Haryana 136119, India

2 Department of Biotechnology, Kurukshetra University, Kurukshetra, Haryana, India

3 Department of Biochemistry, Kurukshetra University, Kurukshetra, Haryana, India

\section{Introduction}

Lignocellulosic residues are low-cost renewable resources luxuriantly available in nature (Anwar et al. 2014; Nanda et al. 2014). Rice straw is one of the abundant lignocellulosic crop residues of the world (Kim and Dale 2004; Rahnama et al. 2014; Singh et al. 2016). The annual global production of rice is about 526 million metric tons (Kim and Dale 2004). Estimates have shown generation of 1.35 tons of rice straw annually for every ton of harvested grain (Kadam et al. 2000). Characteristics of the rice straw, such as low bulk density, high mineral, and silica contents, limit its applications (Jain et al. 2015). Its utilization as animal fodder is also unattractive because of its low digestibility, low protein content, high lignin, and silica contents (Kausar et al. 2010). Therefore, a large part of the rice straw is left unused as a waste. Its disposal is also a problem due to its bulkiness, slow degradation in the nature, and harboring of diseases. It has been seen that burning rice straw in open fields is a common practice all over the world, which leads to air pollution (Gadde et al. 2009; Emtenan et al. 2012; Singh et al. 2016). An alternative to this is using rice straw as a feedstock for production of cellulosic ethanol (Park et al. 2011; Jain et al. 2015).

The cellulosic component of the lignocelluloses is an attractive source of fermentable sugar, the glucose, which can be obtained by enzymatic hydrolysis of the cellulose in a process known as saccharification (Salehi et al. 2012). However, the native cellulose is buried in a matrix of hemicellulose and lignin posing physical barrier to its accessibility. Lignin present as a cover makes the entire structure recalcitrant (Khare et al. 2015). Therefore, hydrolysis is mediated through a crucial step of pretreatment, which opens up the structure of lignocellulose complex (Kumar et al. 2009). Recently, the enzymatic 
saccharification of the cellulose is gaining interest worldwide, especially due to the potential of glucose for its conversion into bioethanol fuel, which can offer a potent alternative to the exhaustible fossil fuel energy sources.

Cellulases are the key enzymes in enzymatic saccharification of the cellulosic biomass (Sukumaran et al. 2009). The complete cellulase system is comprised of endoglucanases, exoglucanases, and $\beta$-glucosidases enzymes, which act synergistically for complete hydrolysis of cellulose to sugars (Sadhu and Maiti 2013). A wide variety of microorganisms, including bacteria, fungi, and actinomycetes, are known to produce cellulases (Wilson 2011). Most of the commercial cellulases production focuses on fungi. Aspergillus niger is among potent cellulase producers (Mrudula and Murugammal 2011). Solid-state fermentation is known to be an efficient technique for the production of hydrolytic enzymes (Sukumaran et al. 2009), in which fungi are cultivated in conditions simulating natural environments. In this study, enhanced cellulases production has been achieved from $A$. niger by parametric optimization under solid-state conditions and the cellulases obtained have been used for the saccharification of pretreated rice straw.

\section{Methodology}

\section{Microorganism, maintenance, and inoculum preparation}

The microorganism used was Aspergillus niger BK01, which was isolated from rice field soil (Goyal et al. 2014a). The culture was maintained on potato dextrose agar (PDA) medium slants and preserved under refrigeration at $4{ }^{\circ} \mathrm{C}$.

For inoculum development, spores of $A$. niger BK01 were inoculated in $30 \mathrm{ml}$ of Potato Dextrose broth (pH 5.0) contained in Erlenmeyer flasks followed with incubation at $28{ }^{\circ} \mathrm{C}$ for $72 \mathrm{~h}$ under stationary conditions. Finally, the spores of activated culture were harvested using sterilized water containing $0.1 \%$ Tween 80 (Smith et al. 1996).

\section{Pretreatment of rice straw}

Rice straw, variety Basmati, was procured from the local fields of Haryana state in India. The biomass was thoroughly washed, then chopped, and dried at $60{ }^{\circ} \mathrm{C}$ till constant weight followed with grinding to the particle size of $0.5 \mathrm{~mm}$. Subsequently, it was subjected to two-stage pretreatment: first with $0.5 \mathrm{M} \mathrm{KOH}$ at room temperature for $4 \mathrm{~h}$, and then with $0.1 \mathrm{~N} \mathrm{H}_{2} \mathrm{SO}_{4}$ at room temperature for $1 \mathrm{~h}$ (bath ratio 1:10) (Goyal et al. 2014b). Subsequently, the biomass was washed using water till neutral $\mathrm{pH}$. The compositional analysis of the biomass for cellulose, hemicellulose, and lignin contents was done using standard biochemical analysis methods (Goerging and van Soest 1975).

\section{Optimization of cellulase production by solid-state fermentation (SSF)}

The solid-state fermentation was carried out using pretreated rice straw. Mandel and Sternburg's medium (1976) (pH 5.0) containing $\mathrm{KH}_{2} \mathrm{PO}_{4}, 0.2 \%$; Urea, $0.03 \%$; $\mathrm{MgSO}_{4} \cdot 7 \mathrm{H}_{2} \mathrm{O}, 0.03 \%, \mathrm{CaCl}_{2}, 0.03 \%$; Peptone, $0.075 \%$, Yeast extract, $0.025 \%$, and trace element solution $\left(\mathrm{FeSO}_{4} \cdot 7 \mathrm{H}_{2} \mathrm{O}, \quad 5 \mathrm{mg} / \mathrm{ml} ; \quad \mathrm{MnSO}_{4} \cdot 4 \mathrm{H}_{2} \mathrm{O}, \quad 1.6 \mathrm{mg} / \mathrm{ml}\right.$; $\mathrm{ZnSO}_{4} \cdot 7 \mathrm{H}_{2} \mathrm{O}, 1.4 \mathrm{mg} / \mathrm{ml}$ and $\mathrm{CoCl}_{2} \cdot 6 \mathrm{H}_{2} \mathrm{O}, 20 \mathrm{mg} / \mathrm{ml}$ ) was used as moistening agent. The solid-to-liquid ratio was maintained as $1: 1.5$. The incubation was done at $25^{\circ} \mathrm{C}$ for $96 \mathrm{~h}$. Cellulase production by the fungus was enhanced by optimizing parameters of substrate concentration $(4.0-9.0 \% \mathrm{w} / \mathrm{v})$, inoculum concentration $(6.0-9.0 \% \mathrm{v} / \mathrm{v})$, incubation period $(24-120 \mathrm{~h}), \mathrm{pH}(4.0-7.0)$, temperature (20-40 $\left.{ }^{\circ} \mathrm{C}\right)$, moisture level (1:1-1:5 biomass to moistening agent ratio), supplementation with carbon $(0.1 \% \mathrm{w} / \mathrm{v}$ maltose, sucrose, carboxymethyl cellulose, cellulose powder, lactose), and nitrogen sources $(0.1 \% \mathrm{w} / \mathrm{v}$ ammonium nitrate, ammonium sulphate, ammonium chloride, beef, tryptone, urea, and potassium nitrate).

\section{Characterization of cellulases}

The enzyme produced from A. niger BK01 was extracted using tenfolds (w/v) of $0.1 \mathrm{M}$ citrate buffer ( $\mathrm{pH} 4.8)$. The contents were mixed thoroughly followed with separation of liquid, which was subjected to centrifugation at $4{ }^{\circ} \mathrm{C}$ at $10,000 \mathrm{rpm}$ for $20 \mathrm{~min}$. Finally, the crude enzyme was obtained by filtering the supernatant through Whatman filter paper no. 1. The crude enzyme was characterized by studying the effect of $\mathrm{pH}$ and temperature on CMCase activity as well as the stability of the enzyme. To study the effect of $\mathrm{pH}$, the enzyme was incubated with buffers of different $\mathrm{pH}$ values (3.0-10.0), i.e., $0.1 \mathrm{M}$ citrate buffer ( $\mathrm{pH}$ 3.0-6.0), $10 \mathrm{mM}$ sodium phosphate buffer $(\mathrm{pH}$ 6.0-8.0), 0.05 M Tris- $\mathrm{HCl}(\mathrm{pH} 8.0-9.0)$, and 0.05 M glycine- $\mathrm{NaOH}$ (pH 9.0-10.0). The effect of temperature was studied by carrying out reactions at different temperatures ranging from $20-60{ }^{\circ} \mathrm{C}$.

\section{Optimization of saccharification of rice straw}

The crude enzyme produced by $A$. niger BK01, under optimized conditions of SSF, was used for saccharification of the pretreated rice straw. To optimize the saccharification conditions, the effect of different concentrations of enzyme (loaded @ 1.0, 1.5, 2.0 and 2.5\% v/v) and 
incubation time $(0.5-3.0 \mathrm{~h})$ was studied. The reaction was carried out at $40{ }^{\circ} \mathrm{C}$ using alkali-assisted acid pretreated rice straw at $10 \%(\mathrm{w} / \mathrm{v})$ concentration and the amount of reducing sugars released was determined. Finally, the percent saccharification was calculated using formula: (Reducing sugars produced $\times 0.9 \times$ dilutions/amount of the cellulose) $\times 100$ (Begum and Alimon 2011)

\section{Enzyme assay}

Carboxymethyl cellulase (CMCase/endoglucanase) activity was assayed by the DNS (3, 5-dinitrosalicylic acid) method (Miller 1959). The reaction mixture consisted of $900 \mu \mathrm{l}$ of substrate (CMC in $0.1 \mathrm{M}$ citrate buffer, $\mathrm{pH} 4.8$ ) and $100 \mu \mathrm{l}$ of crude enzyme and was incubated at $35{ }^{\circ} \mathrm{C}$ for $60 \mathrm{~min}$. The reaction was terminated by adding $3 \mathrm{ml}$ of 3,5-dinitrosalicylic acid reagent. The tubes were incubated for $15 \mathrm{~min}$ in a boiling water bath for the color development and the contents were cooled rapidly. The activity of the reaction mixture was measured against a reagent blank at $540 \mathrm{~nm}$. The concentration of the glucose released by the enzyme was determined by comparing against a standard curve plotted similarly using known concentrations of glucose. One enzyme unit (IU) is defined as the amount of enzyme required to hydrolyze $1 \mu \mathrm{g}$ of substrate per min under the assay conditions. The amount of the enzyme production was expressed as units per gram dry substrate (U/gds).

\section{Results and discussion}

\section{Pretreatment of rice straw}

Alkali-assisted acid pretreatment resulted in the change in the biomass composition, i.e., increase in the cellulose content as a result of the decrease in lignin and hemicellulose contents during alkali and acid pretreatments, respectively (Goyal et al. 2014a, b); (Table 1).

\section{Optimization of cultural conditions for cellulase production under solid-state fermentation conditions}

\section{Effect of substrate concentration}

Optimum substrate concentration is an essential requirement of the SSF to ensure the appropriate growth of microorganisms. On studying the effect of the substrate concentration $(4.0-9.0 \%$, w/v), it was found that the CMcase production by A. niger BK01 increased maximum to $8.52 \pm 0.04 \mathrm{U} / \mathrm{gds}$ when the concentration was raised from 4 to $6 \%$ (Fig. 1). However, an increase in concentration beyond $6 \%$ resulted in
Table 1 Effect of pretreatment on biomass composition of rice straw Lignocellulosic content Untreated biomass Pretreated biomass

\begin{tabular}{lcr}
\hline Cellulose $(\% \mathrm{w} / \mathrm{w})$ & $38.40 \pm 1.40$ & $59.50 \pm 1.54(54.94) \uparrow$ \\
Hemicellulose $(\% \mathrm{w} / \mathrm{w})$ & $24.0 \pm 1.50$ & $8.26 \pm 0.23(65.58) \downarrow$ \\
Lignin $(\% \mathrm{w} / \mathrm{w})$ & $19.0 \pm 1.0$ & $5.17 \pm 0.10(72.78) \downarrow$ \\
\hline
\end{tabular}

Figures in parenthesis indicate $\%$ change in the value due to alkali + acid pretreatment as compared to the values for untreated sample

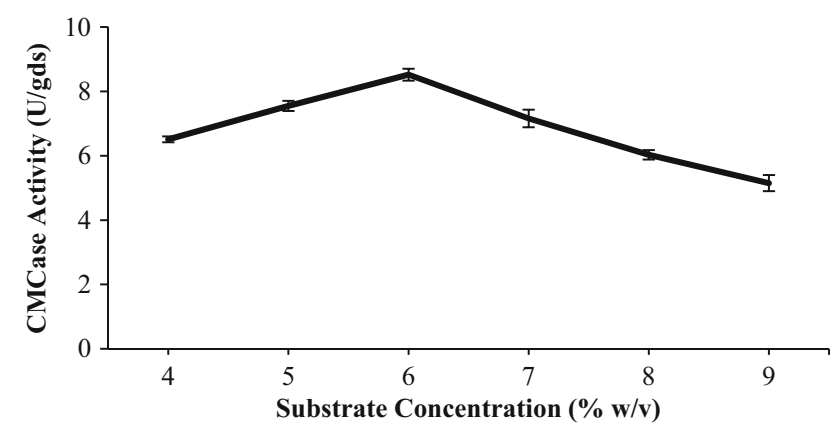

Fig. 1 Effect of substrate concentration on CMCase production by $A$. niger BK01 under SSF (fermentation conditions: $\mathrm{pH} 5.0 ; 6.0 \% \mathrm{v} / \mathrm{v}$ inoculum size; temperature $25^{\circ} \mathrm{C}$; incubation time $96 \mathrm{~h}$; solid to liquid ratio $1: 1.5$ )

a decline in the activity. This can be attributed to the fact that high substrate concentration results in lower enzyme yields due to the inhibitory effect of the byproducts released in large quantities (Ramos et al. 1993). Different levels of the substrate are required depending on the type of the substrate and the microbial species. In a study by Gori and Malana (2010), $4 \%$ wheat straw was found optimum for maximum CMCase production by Aspergillus sp. Sherief et al. (2010) reported $5 \%$ rice straw as the best substrate concentration under SSF conditions. In another study, $3 \%$ substrate concentration was found suitable for maximum CMCase production by Trichoderma viride (Ahmed et al. 2010) and Trichoderma harzianum (Iqbal et al. 2010) under SSF using wheat straw.

\section{Effect of inoculum size}

Fungal sporulation and metabolic activities are greatly influenced by the size of the inoculum (Domingues et al. 2000). On studying the effect of different inoculum levels $(6.0-9.0 \%, \mathrm{v} / \mathrm{v})$, maximum CMCase activity of $8.84 \pm 0.07 \mathrm{U} / \mathrm{gds}$ was recorded at $7.5 \%$ inoculum level (Fig. 2). The results highlight the importance of the inoculum density in SSF. Lower inoculum size requires longer time for fungal multiplication and substrate utilization, whereas higher inoculum size increases the spore density as well as the water content in the medium causing hindrance in oxygen penetration resulting in the inhibited fungal growth and enzyme production ( $\mathrm{Vu}$ et al. 2011). 


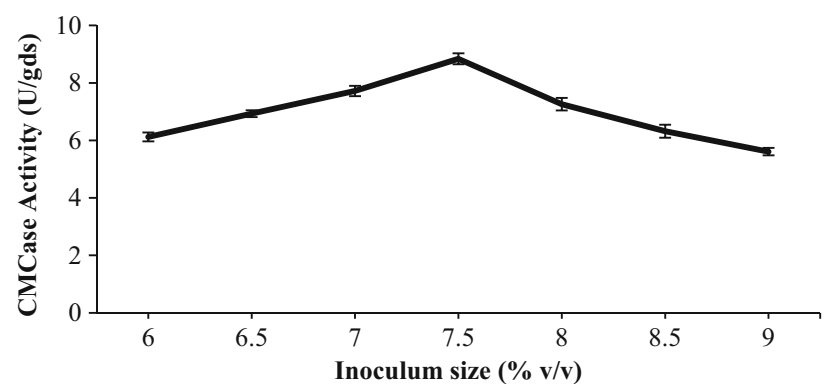

Fig. 2 Effect of inoculum size on CMCase production by A. niger BK01 under SSF (fermentation conditions: $\mathrm{pH} 5.0 ; 6.0 \% \mathrm{w} / \mathrm{v}$ substrate concentration; temperature $25{ }^{\circ} \mathrm{C}$; incubation time $96 \mathrm{~h}$; solid to liquid ratio $1: 1.5$ )

Fadel (2001) reported maximum cellulase activity by $A$. niger with $10 \%$ inoculum size using wheat straw as a substrate. Omojasola and Jilani (2009) reported 8\% inoculum size suitable for maximum cellulase production by A. niger. Murad and Azzaz (2013) have reported 7\% inoculum size optimum for maximum cellulase production by Aspergillus flavus using rice straw.

\section{Effect of incubation time}

CMCase production by $A$. niger BK01 reached maximum levels after $96 \mathrm{~h}$ of incubation yielding $9.06 \pm 0.06 \mathrm{U} / \mathrm{gds}$ of CMCase. Thereafter, the enzyme production started decreasing significantly (Fig. 3). This could be due to the loss of moisture, denaturation of the enzyme as a result of variation in $\mathrm{pH}$ during fermentation, or the accumulative effect of cellobiose inhibitory to the CMCase enzyme (Melo et al. 2007; Singh et al. 2009). The optimal incubation time varies with the type and composition of the fermentation medium, initial $\mathrm{pH}$, and different fungal species employed for enzyme production. Similar to our observations, Milala et al. (2005) and Ilyas et al. (2011) also reported maximum CMCase production by A. niger in $96 \mathrm{~h}$. In other studies, the optimal incubation period for maximum CMCase production was documented to be 3, 5, and 10 days in Aspergillus sp. SU14-M15 (Vu et al. 2011), Trichoderma reesei (Fatma et al. 2010), and Rhizopus stolonifer (Pothiraj et al. 2006), respectively, using different substrates. The reports have indicated that the optimum time for the synthesis of cellulolytic enzymes during SSF of lignocellulosic residues lies in the range of 3-8 days (Jecu 2000; Panagiotou et al. 2003; Narasimha et al. 2006).

\section{Effect of $\mathrm{pH}$}

On studying the effect of initial $\mathrm{pH}$, the maximum production of CMCase, i.e., $9.54 \pm 0.06 \mathrm{U} / \mathrm{gds}$, was observed at $\mathrm{pH} 5.5$ (Fig. 4). Optimal $\mathrm{pH}$ is an important parameter for the microbial growth as well as the enzyme production.

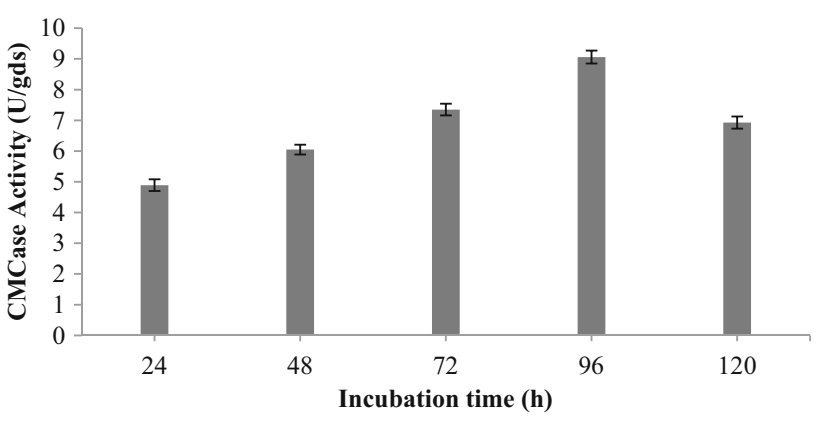

Fig. 3 Effect of incubation time on CMCase production by A. niger BK01 under SSF (fermentation conditions: $\mathrm{pH} 5.0 ; 6.0 \% \mathrm{w} / \mathrm{v}$ substrate concentration; $7.5 \% \mathrm{v} / \mathrm{v}$ inoculum size; temperature $25^{\circ} \mathrm{C}$; solid to liquid ratio $1: 1.5$ )

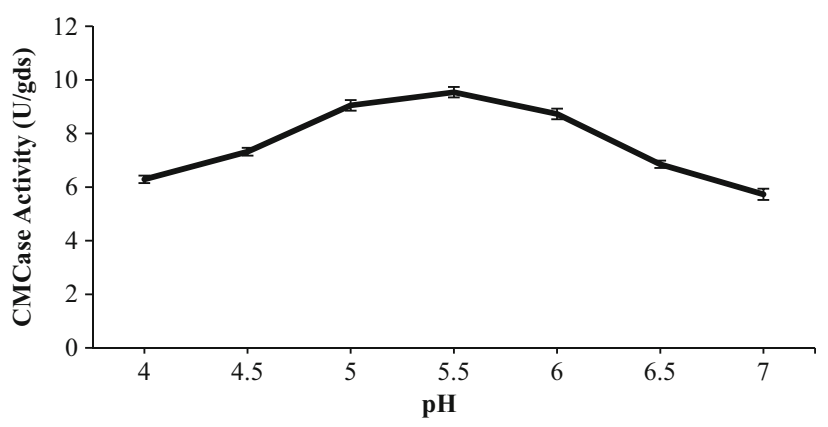

Fig. 4 Effect of $\mathrm{pH}$ on CMCase production by A. niger BK01 (fermentation conditions: $6.0 \% \mathrm{w} / \mathrm{v}$ substrate concentration; $7.5 \% \mathrm{v} / \mathrm{v}$ inoculum size; temperature $25^{\circ} \mathrm{C}$; solid to liquid ratio $1: 1.5$; incubation time $96 \mathrm{~h}$ )

A $\mathrm{pH}$ value lower or higher than the optimum affects the metabolic activities of the organism. It also influences stability of the enzyme and may lead to the protein denaturation (Kalra and Sandhu 1986). In different fungal species, the optimum $\mathrm{pH}$ for CMCase production has been found to vary from 3.0 to 6.0 (Rodriguez et al. 2005; Niranjane et al. 2007). Different workers have reported an optimum $\mathrm{pH}$ of 5.5 for maximum CMCase production by A. niger AT-3 (Dutt and Kumar 2014), Aspergillus fumigatus (Sherief et al. 2010), T. viride (Ahmed et al. 2010), and T. reesei RUT-C30 (Haq et al. 2001; Xiong et al. 2004). Fadel (2001) found $\mathrm{pH} 4.5$ optimal for maximum CMCase synthesis by A. niger under SSF. Acharya et al. (2008) documented that optimum $\mathrm{pH}$ for cellulase production by $A$. niger, using saw dust substrate, was between 4.0 and 4.5. Sohail et al. (2009) have found more acidic $\mathrm{pH}$, i.e., 4.0 optimal for cellulases production by A. niger MS82.

\section{Effect of incubation temperature}

Temperature strongly affects the SSF process. Optimization of temperature is essential, because it significantly 


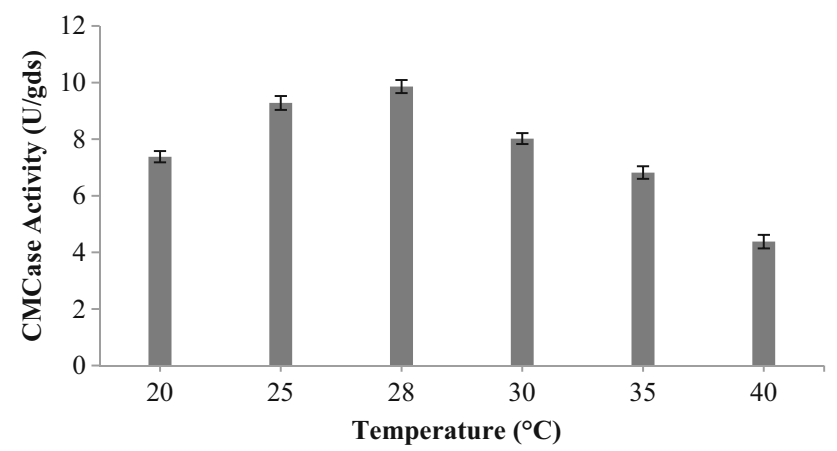

Fig. 5 Effect of incubation temperature on CMCase production by $A$. niger BK01 (fermentation conditions: $6.0 \% \mathrm{w} / \mathrm{v}$ substrate concentration; $7.5 \% \mathrm{v} / \mathrm{v}$ inoculum size; solid to liquid ratio 1:1.5; incubation time $96 \mathrm{~h} ; \mathrm{pH} 5.5$ )

influences the metabolic activities of an organism. A temperature lower or higher than the optimum may lead to the decreased transport across cell envelope or enzyme denaturation, respectively (Dutt and Kumar 2014). It also plays a vital role in production of the end-products (Ahmed et al. 2009). Even slight changes in the temperature can affect the enzyme production. In the present work, maximum production of CMCase by A. niger BK01 was achieved at $28{ }^{\circ} \mathrm{C}$ resulting in $9.86 \pm 0.05 \mathrm{U} /$ gds enzyme activity (Fig. 5). Similarly, $28{ }^{\circ} \mathrm{C}$ temperature was found suitable for maximum CMCase production by $T$. reesei (Singhania et al. 2006) and A. niger (Acharya et al. 2008). In other studies, an optimum temperature of around $30 \pm 2{ }^{\circ} \mathrm{C}$ has been reported for CMCase production by $A$. niger (Ilyas et al. 2011; Mrudula and Murugammal 2011). Dutt and Kumar (2014) have found $35^{\circ} \mathrm{C}$ temperature optimum for highest levels of cellulases synthesis by $A$. niger AT-3.

\section{Effect of moisture level on CMCase production}

To determine the effect of moisture level, the substrate was moistened by Mandel and Sternburg's medium in different solid-to-liquid ratios ranging from 1:1 to 1:5. A ratio of 1:2 was found to be best for producing highest levels of CMCase (10.98 $\pm 0.07 \mathrm{U} / \mathrm{gds})$ by A. niger BK01 (Fig. 6). Moisture is the most significant factor in the solid-state fermentation. The efficiency of the mass transfer in the solid-phase particles depends on the substrate characteristics and the appropriate moisture (Liu and Yang 2007). Very high moisture content results in decreased substrate porosity and reduced oxygen penetration ( $\mathrm{Vu}$ et al. 2010). On the other hand, excessively low moisture levels lead to poor microbial growth and poor accessibility to nutrients (Vu et al. 2010). Narasimha et al. (2006) reported that

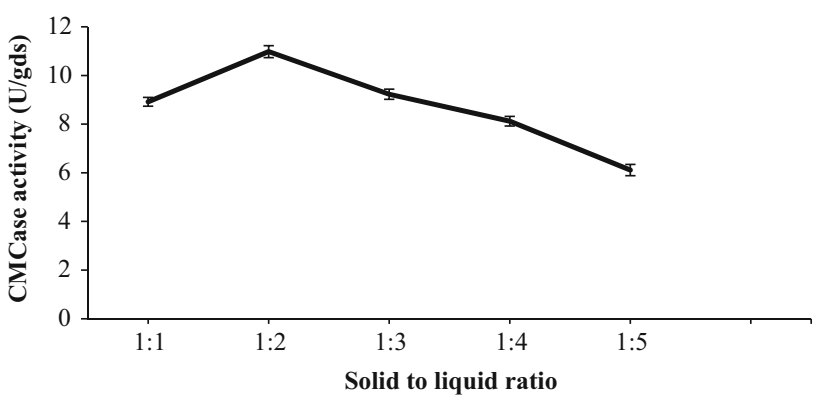

Fig. 6 Effect of moisture level on CMCase production by A. niger BK01 under SSF (fermentation conditions: $6.0 \%$ w/v substrate concentration; $7.5 \% \mathrm{v} / \mathrm{v}$ inoculum size; incubation time $96 \mathrm{~h} ; \mathrm{pH}$ 5.5; temperature $28{ }^{\circ} \mathrm{C}$ )

optimal water levels in the solid substrate appear to be 40-60\% (by mass) under solid-state fermentation conditions. Fatma et al. (2010) demonstrated a ratio of 1:3 (substrate: moistening agent) optimal for maximum CMCase production by $T$. reesei. In another study by $\mathrm{Vu}$ et al. (2011), maximum CMCase production by Aspergillus sp. SU14 was observed using 50\% moisture content, whereas $70 \%$ moisture content was found suitable for maximum cellulase production by $A$. niger (Ilyas et al. 2011).

\section{Effect of carbon sources}

The SSF production medium was supplemented with different carbon sources $(0.1 \% \mathrm{w} / \mathrm{v})$, from which $\mathrm{CMC}$ showed the stimulatory effect for maximum CMCase $(11.75 \pm 0.05 \mathrm{U} / \mathrm{gds})$ production by the fungus $A$. niger BK01 (Fig. 7). In a study by Irfan et al. (2012), an increase in CMCase production was recorded in $T$. viride on addition of CMC $(0.5 \%)$ in the fermentation medium as a carbon source. On the other hand, Vu et al. (2011) mentioned that CMCase was expressed maximum when Aspergillus sp. SU14-M15 was grown in the presence of $(1 \%)$ rice starch and corn starch under solid-state fermentation. Irfan et al. (2011) documented glucose as the best additional carbon source while producing CMCase from Aspergillus sp. It is evident from various research studies that the cellulolytic systems in different fungi are induced to different levels in the presence of diverse sources of carbon (Amore et al. 2013). The presence of an easily utilizable form of carbon, supportive for the growth of the fungus, may not be inductive for high cellulase production by the same fungal species (Tong and Rajendra 1992). A study by Nazir et al. (2010) has also shown differential expression of endoglucanases and $\beta$-glucosidases isoforms by A. terreus in the presence of different carbon sources and culture conditions. 


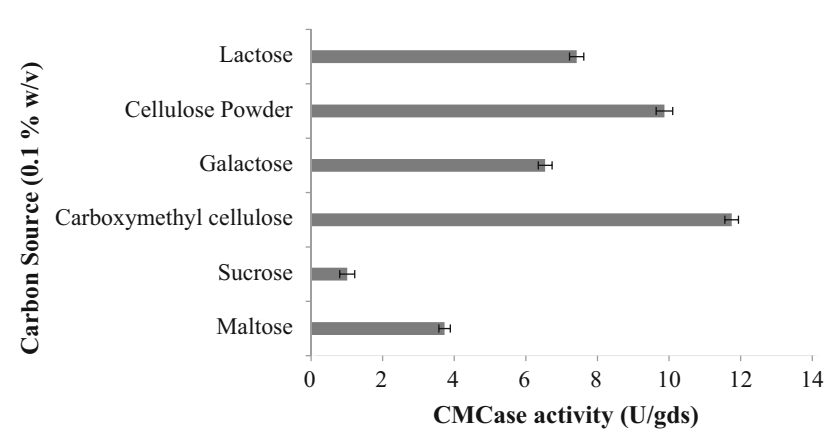

Fig. 7 Effect of carbon source on CMCase production by A. niger BK01 (fermentation conditions: $6.0 \% \mathrm{w} / \mathrm{v}$ substrate concentration; $7.5 \% \mathrm{v} / \mathrm{v}$ inoculum size; incubation time $96 \mathrm{~h} ; \mathrm{pH} 5.5$; temperature $28{ }^{\circ} \mathrm{C}$; solid to liquid ratio $1: 2$ )

\section{Effect of nitrogen sources}

The presence of additional nitrogen sources along with the nitrogenous compounds present in the substrate could promote enhanced growth and consequent enzyme production. The effect of various nitrogen sources $(0.1 \% \mathrm{w} / \mathrm{v})$ was, therefore, studied on CMCase production by A. niger BK01. The results depicted highest levels of CMCase $(12.0 \pm 0.07 \mathrm{U} / \mathrm{gds})$ production by the fungus in the presence of ammonium nitrate (Fig. 8). Nitrogen is one of the major elements of cellular proteins. The stimulation of cellulase activity by the ammonium salts might be due to their direct entry in the protein synthesis (Mandels 1975). In a study by Gokhale et al. (1991), A. niger NCIM 1207 showed enhanced cellulase production in the presence of ammonium sulphate, ammonium dihydrogen orthophosphate, and corn-steep liquor. Singhania et al. (2006) also observed that ammonium nitrate increased the CMCase production by $T$. reesei NRRL 11460 during SSF. Vyas et al. (2005) found ammonium sulphate suitable for maximum CMCase production by Aspergillus terrus using pretreated groundnut shells. In another study on CMCase production by $A$. niger under solid-state fermentation, $0.1 \%$

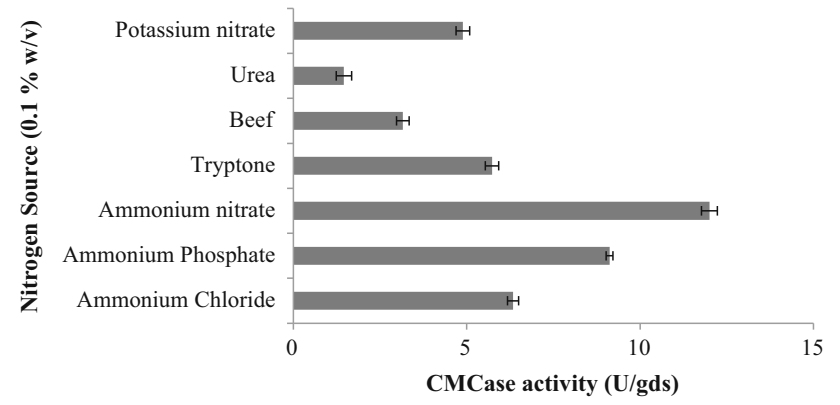

Fig. 8 Effect of nitrogen sources on CMCase production by A. niger BK01 (fermentation conditions: $6.0 \%$ w/v substrate concentration; $7.5 \% \mathrm{v} / \mathrm{v}$ inoculum size; incubation time $96 \mathrm{~h}$; $\mathrm{pH}$ 5.5; temperature $28{ }^{\circ} \mathrm{C}$; solid to liquid ratio $1: 2 ; 0.1 \%$ w/v CMC) peptone was recorded as the best nitrogen source (Acharya et al. 2008). Like carbon sources, the nitrogen sources also cause differential expression of cellulolytic genes in different microbial species to different levels.

\section{Characterization of cellulases}

\section{Effect of $\mathrm{pH}$ on activity and stability of enzyme}

The optimum $\mathrm{pH}$ level for the enzyme activity was determined by incubating crude enzyme from A. niger BK01 with $\mathrm{CMC}$ at different $\mathrm{pH}$ levels. Highest CMCase activity of the enzyme was observed at $\mathrm{pH}$ 4.8. However, the optimum $\mathrm{pH}$ range recorded for CMCase activity $(>80 \%)$ was 4.8-6.0. The enzyme showed $>80 \%$ stability in the $\mathrm{pH}$ range of $4.8-5.5$ (Fig. 9). From the results, it was concluded that the CMCase from the fungal isolate needed an acidic environment to be active. Increasing or decreasing $\mathrm{pH}$ beyond optimum range resulted in a significant decline in the enzyme activity. Any change in the $\mathrm{pH}$ is known to cause changes in the enzyme's active site resulting in a change in the enzyme activity. Akiba et al. (1995) reported $\mathrm{pH}$ 6.0-7.0 optimum for CMCase from A. niger. Saha (2004) reported $\mathrm{pH}$ range 4.0-7.0 optimum for activity of CMCase from $M$. circinelloides. Cellulases produced from Chrysosporium lucknowense and A. fumigatus were found stable at pH 5.0 (Gusakov et al. 2005; Sherief et al. 2010).

\section{Effect of temperature on activity and stability of enzyme}

Activity and stability of the crude cellulase from $A$. niger BK01 were also tested at different temperatures. It was found that activity of the CMCase increased rapidly when the temperate was raised from 20 to $30{ }^{\circ} \mathrm{C}$. The enzyme showed $>80 \%$ activity in the range of $30-50{ }^{\circ} \mathrm{C}$ and highest activity was recorded at $40^{\circ} \mathrm{C}$. However, an increase in temperature beyond $50{ }^{\circ} \mathrm{C}$ resulted in a sharp decline in the activity. This could be due to the reason that increasing temperature beyond the optimum value causes a

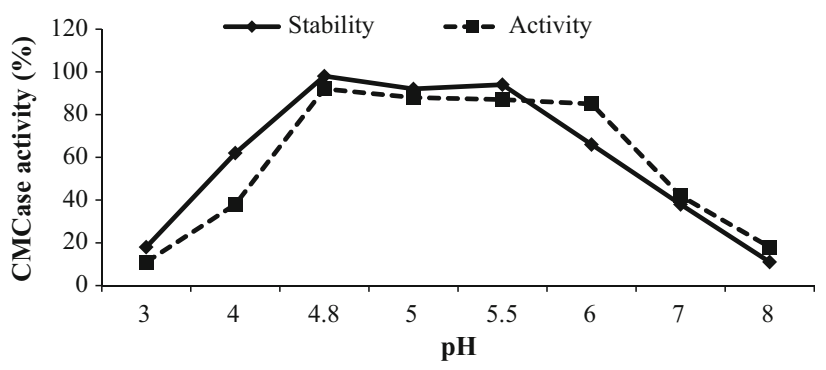

Fig. 9 Effect of different $\mathrm{pH}$ on activity and stability of crude CMCase from A. niger BK01 


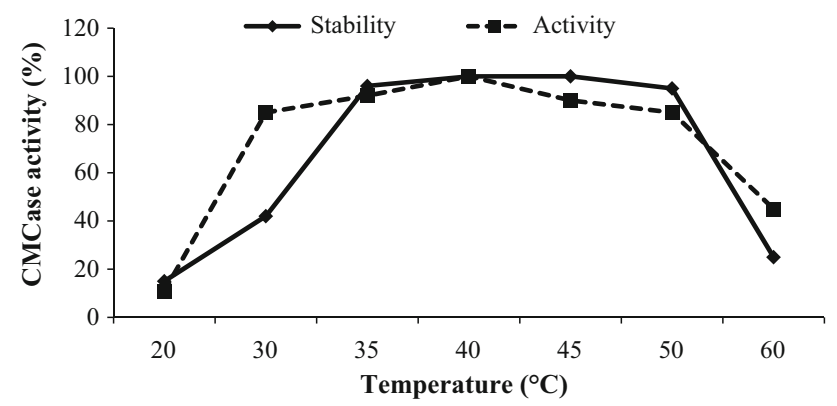

Fig. 10 Effect of different temperatures on activity and stability of crude CMCase from A. niger BK01

decrease in the catalytic rate of the enzyme as a result of its denaturation. The stability $(>80 \%)$ of the crude enzyme was achieved in the range of $35-50{ }^{\circ} \mathrm{C}$ (Fig. 10). El-Azab (2007) reported that $45-55{ }^{\circ} \mathrm{C}$ temperature is optimum range for CMCase activity. Optimum temperatures reported by other workers were $55{ }^{\circ} \mathrm{C}$ for that from $T$. viride (Sharma et al. 1991) and $40^{\circ} \mathrm{C}$ for that from A. fumigatus (Sherief et al. 2010). On the other hand, the crude cellulases of $M$. circinelloides showed an optimum temperature of $55{ }^{\circ} \mathrm{C}$ (Saha 2004).

\section{Saccharification optimization}

The crude cellulase enzyme produced from A. niger BK01 using pretreated rice straw, through SSF under optimized conditions, was used for saccharification of the alkali-assisted acid pretreated rice straw. The different enzyme preparations were loaded @ 1, 1.5, 2, 2.5\% (v/v) concentrations and hydrolysis was carried out for different time intervals at $40{ }^{\circ} \mathrm{C}$ and $\mathrm{pH} 4.8$. The results showed maximum hydrolysis of the biomass occurred in $2.5 \mathrm{~h}$. Increasing the enzyme loadings from 1 to $2 \%$ enhanced the rate of saccharification. Further increase in the enzyme concentration released lesser amounts of the sugars.

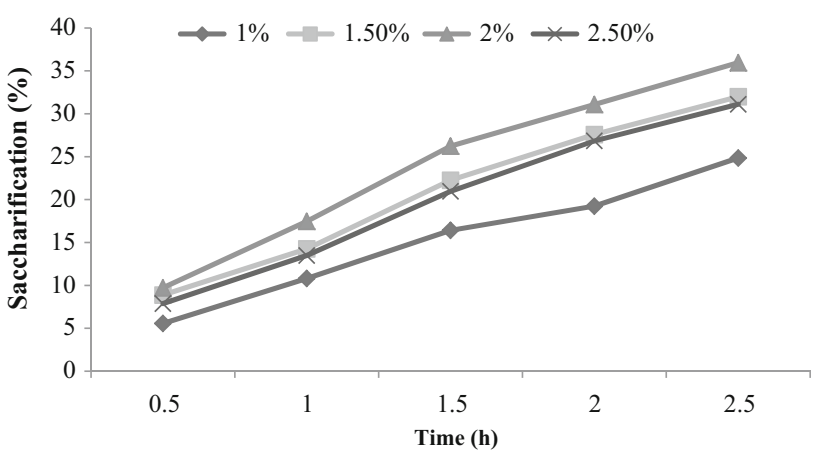

Fig. 11 Effect of A. niger BK01 crude cellulase enzyme concentration on saccharification of pretreated rice straw

Maximum 23.78\% sugars were released after $2.5 \mathrm{~h}$ incubation period with cellulase loading of $2 \%$ (Table 2). The highest saccharification value recorded under optimized conditions was $35.96 \%$ (Fig. 11; Table 3).

Many workers have used microbial enzymes for the hydrolysis of lignocellulosic materials. The saccharification of cotton, filter paper, and newspaper using $T$. viride culture filtrate resulted in a saccharification rate of 9.9, 59.4, and $41.8 \%$, respectively (Mandels et al. 1974). The rate of saccharification was 3.5, 1.5, and 3.0\% during hydrolysis of the saw dust, filter paper, and newspaper, respectively, using Sporotrichum thermophile culture filtrate (El-Naghy et al. 1991). Ja' afaru and Fagade (2007) achieved 5.0\% saccharification rate for treated corn cob using A. niger crude enzyme. Wati et al. (2007) reported the hydrolysis of alkalitreated paddy straw with a commercial preparation of cellulase resulting in the release of $65 \%$ total reducing sugars. Fatma et al. (2010) reported enzymatic saccharification of alkali-treated rice straw with cellulases of $T$. ressei and observed maximum glucose yield of $1.07 \%$ after $16 \mathrm{~h}$ of incubation. Another work by Kumar and Pushpa (2012) showed the release of $73.30 \mathrm{mg} / \mathrm{g}$ of reducing sugars after treatment of rice straw by $T$. reesei.

Table 2 Effect of cellulase concentration on the total reducing sugars released from pretreated rice straw at different time intervals with fungal crude cellulase enzyme from A. niger BK01

\begin{tabular}{llrrr}
\hline Time $(\mathrm{h})$ & \multicolumn{4}{l}{ Total reducing sugars $(\% \mathrm{w} / \mathrm{w})$ at different enzyme concentration $(\% \mathrm{v} / \mathrm{v})$} \\
\cline { 2 - 5 } & \multicolumn{1}{l}{1} & \multicolumn{1}{l}{1.5} & \multicolumn{2}{c}{} \\
\hline 0.5 & $3.68 \pm 0.22$ & $5.87 \pm 0.17$ & $6.43 \pm 0.06$ & $5.21 \pm 0.10$ \\
1.0 & $7.15 \pm 0.31$ & $9.43 \pm 0.25$ & $11.55 \pm 0.29$ & $8.92 \pm 0.17$ \\
1.5 & $10.86 \pm 0.32$ & $14.72 \pm 0.21$ & $20.56 \pm 0.15$ & $13.86 \pm 0.23$ \\
2.0 & $12.72 \pm 0.11$ & $18.24 \pm 0.16$ & $23.78 \pm 0.13$ & $17.78 \pm 0.11$ \\
2.5 & $16.43 \pm 0.02$ & $21.15 \pm 0.04$ & $20.57 \pm 0.19$ \\
\hline
\end{tabular}

Alkali-assisted acidic pretreated rice straw was used at $10 \%$ conc. and reaction was carried out at $40{ }^{\circ} \mathrm{C}$ 
Table 3 Saccharification study of pretreated rice straw using crude cellulase enzyme from A. niger BK01

\begin{tabular}{lllll}
\hline Enzyme & $\begin{array}{l}\text { Pretreated rice straw } \\
\text { concentration }\end{array}$ & $\begin{array}{l}\text { Reducing sugar }(\mathrm{g} / \mathrm{g} \text { of } \\
\text { substrate) }\end{array}$ & $\begin{array}{l}\text { Reducing sugar (g/g of } \\
\text { cellulose) }\end{array}$ & $\begin{array}{l}\text { Saccharification } \\
\text { value }\end{array}$ \\
\hline $\begin{array}{l}\text { Crude cellulase enzyme from A. niger } \\
\text { isolate BK01 }\end{array}$ & $10 \mathrm{~g}(5.95 \mathrm{~g})$ & 0.2378 & 0.3996 & 35.96 \\
\hline
\end{tabular}

Figures in parenthesis indicate the cellulose present in the substrate

Conditions: substrate concentration $10 \% \mathrm{w} / \mathrm{v}$, Enzyme loading $2 \% \mathrm{v} / \mathrm{v}, 40{ }^{\circ} \mathrm{C}, \mathrm{pH} 4.8$, time $2.5 \mathrm{~h}$

\section{Conclusion}

Rice straw is a common agricultural waste worldwide and its disposal has been a concern. Lignocellulosic nature of the rice straw, however, makes it an economic substrate for production of biomass hydrolyzing enzymes, such as cellulases. Moreover, it can also serve as an easily procurable feedstock for production of bioethanol. This study, therefore, deals with production of cellulases by A. niger BK01 using pretreated rice straw and utilizing the enzymes for saccharification of the straw. Solid-state fermentation is an effective process for production of enzymes in large quantities. Therefore, cultural conditions were optimized for maximization of cellulases production by the fungus. $12.0 \mathrm{U} / \mathrm{gds}$ of endoglucanases' synthesis was achieved using $6.0 \%$ substrate, $7.5 \%$ inoculum, $5.5 \mathrm{pH}, 28{ }^{\circ} \mathrm{C}$ temperature, and by adding $0.1 \% \mathrm{CMC}$ and $0.1 \%$ ammonium nitrate in the fermentation medium. Furthermore, under optimized conditions of saccharification, the cellulases hydrolyzed the pretreated biomass successfully resulting in the release of appreciable amounts of sugars $(23.78 \%)$, with a saccharification value of $35.96 \%$. The study can be extended in future for the production of bioethanol from the rice straw. In addition, the saccharification ability of A. niger BK01 can be exploited for the hydrolysis of the other lignocellulosic biomass.

Acknowledgements The authors express their sincere gratitude to the Haryana State Council of Science and Technology (HSCST), Haryana, India, for providing the financial aid for this research work.

\section{Compliance with ethical standards}

Conflict of interest The authors declare that there is no conflict of interest regarding publication of this paper.

\section{References}

Acharya PB, Acharya DK, Modi HA (2008) Optimization for cellulase production by Aspergillus niger using saw dust as substrate. Afr J Biotechnol 22:4147-4152

Ahmed S, Bashir A, Saleem H, Saadia M, Jamil A (2009) Production and purification of cellulose degradaing enzymes from a filamentous fungus Trichoderma harzianum. Pak $\mathrm{J}$ Bot 41:1411-1419
Ahmed I, Zia MA, Iqbal HMN (2010) Bioprocessing of proximally analyzed wheat straw for enhanced cellulase production through process optimization with Trichoderma viride under SSF. Int $\mathbf{J}$ Biol Life Sci 6:164-170

Akiba S, Kimura Y, Yamamoto K, Kumagai H (1995) Purification and characterization of a protease-resistant cellulase from Aspergillus niger. J Ferment Bioeng 79:125-130

Amore A, Giacobbe S, Faraco V (2013) Regulation of cellulase and hemicellulose gene expression in fungi. Curr Genom 14:230-249

Anwar Z, Gulfraz M, Irshad M (2014) Agro-industrial lignocellulosic biomass a key to unlock the future bio-energy: a brief review. J Radiat Res Appl Sci 7:163-173

Begum MF, Alimon AR (2011) Bioconversion and saccharification of some lignocellulosic wastes by ITCC 4857.01 for fermentable sugar production. Electron J Biotechnol 14:1-6

Domingues FC, Queiroz JA, Cabrad JM, Fonseca LP (2000) The influence of culture conditions on mycelia structure and cellulase production by Trichoderma reesei Rut C-30. Enzyme Microb Technol 26:394-401

Dutt D, Kumar A (2014) Optimization of cellulase production under solid state fermentation by Aspergillus flavus (AT-2) and Aspergillus niger (AT-3) and its impact on stickies and ink particle size of sorted office paper. Cellul Chem Technol 48:285-298

El-Azab NT (2007) Bioconversion of some agricultural wastes by fungi. M.D. Thesis, Botany Department, Faculty of Science, Mansoura University, Egypt

El-Naghy MA, El-Katatny MS, Attia AA (1991) Degradation of cellulosic materials by Sporotrichum thermophile culture filtrate for sugar production. Int Biodeterior 27:75-79

Emtenan M, Hanafi HHE, Khadrawy WM, Ahmed MM (2012) Some observations on rice straw with emphasis on updates of its management. World Appl Sci J 16:354-361

Fadel M (2001) Production physiology of cellulases and $\beta$-glucosidase enzymes of Aspergillus niger grown under solid state fermentation conditions. Online J Biol Sci 1:401-411

Fatma H, El-Zaher Abd, Fadel M (2010) Production of bioethanol via enzymatic saccharification of rice straw by cellulase produced by Trichoderma reesei under solid state fermentation. N Y Sci J 3:72-78

Gadde B, Bonnet S, Menke C, Garivait S (2009) Air pollutant emissions from rice straw open field burning in India, Thailand and the Philippines. Environ Pollut 157:1554-1558

Goerging HD, van Soest JP (1975) Forage Fibre Analysis. US Department of Agriculture, Agricultural Research Service, Washington

Gokhale DV, Patil SG, Bastawde KB (1991) Optimization of cellulase production by Aspergillus niger NCIM 1207. Appl Biochem Biotechnol 30:99-109

Gori MI, Malana MA (2010) Production of carboxymethyl cellulase from local isolate of Aspergillus species. Pak J Life Soc Sci $8: 1-6$ 
Goyal A, Aggarwal NK, Bhuwal A, Yadav A (2014a) Optimization of CMCase production by Aspergillus niger BK01 using pretreated rice straw under submerged fermentation. Octa J Biosci 2:94-98

Goyal A, Mittal A, Bhuwal AK, Singh G, And Yadav A, Aggarwal NK (2014b) Parametric optimization of cultural conditions for carboxymethyl cellulase production using pretreated rice straw by Bacillus sp. 313SI under stationary and shaking conditions. Biotechnol Res Int 2014:1-7

Gusakov AN, Sinitsyn AP, Salanovich TN, Bukhtojarov FE, Markov AV, Ustinov BB, van Zeijl C, Punt P, Burlingame R (2005) Purification, cloning and characterisation of two forms of thermostable and highly active cellobiohydrolase I (Cel7A) produced by the industrial strain of Chrysosporium lucknowense. Enzyme Microb Technol 36:57-69

Haq I, Khurshid S, Ali S, Ashraf H, Qadeer MA, Rajoka MI (2001) Mutation of Aspergillus niger for hyper-production of citric acid from black strap molasses. World J Microbiol Biol 17:35-37

Ilyas U, Majeed A, Hussain K, Nawaz K, Ahmed S, Nadeem M (2011) Solid state fermentation of Vigna mungo for cellulase production by Aspergillus niger. World Appl Sci J 12:1172-1178

Iqbal HMN, Asgher M, Ahmed I, Hussain S (2010) Media optimization for hyper-production of carboxymethyl cellulase using proximally analyzed agro-industrial residue with Trichoderma harzianum under SSF. Int J Agro Vet Med Sci 4:47-55

Irfan M, Irfan U, Razzaq Z, Syed Q, Nadeem M (2011) Utilization of agricultural wastes as substrate for carboxymethyl cellulase production from Aspergillus niger in submerged fermentation. Int J Agro Vet Med Sci 5:464-471

Irfan M, Nadeem M, Syed Q (2012) Influence of nutritional conditions for endoglucanase production by Trichoderma viride in SSF. Glob J Biotechnol Biochem 7:7-12

Ja' afaru MI, Fagade OE (2007) Cellulase production and enzymatic hydrolysis of some selected local lignocellulosic substrates by a strain of Aspergillus niger. Res J Biol Sci 2:13-16

Jain RK, Ghosh D, Agrawal D, Suman SK, Pandey D, Vadde VT, Dixit AK, Adhikari DK, Dasgupta D (2015) Ethanol production from rice straw using thermotolerant Kluyveromyces $\mathrm{sp}$. IIPE453. Biomass Convers Biorefin 5:331-337

Jecu L (2000) Solid state fermentation of agricultural wastes for endoglucanase production industry. Crops Prod 11:1-5

Kadam KL, Forrest LH, Jacobson WA (2000) Rice straw as a lignocellulosic resource: collection, processing, transportation, and environmental aspects. Biomass Bioenergy 18:369-389

Kalra MK, Sandhu DK (1986) Optimal production of cellulolytic enzymes and their location in Trichoderma pseudokoningii. Acta Biotechnol 6:161-166

Kausar H, Sariah M, Saud HM, Alam MZ, Ismail MR (2010) Isolation and screening of potential actinobacteria for rapid composting of rice straw. Biodegradation 22:367-375

Khare SK, Pandey A, Larroche C (2015) Current perspectives in enzymatic saccharification of lignocellulosic biomass. Biochem Eng J XXX:1-7

Kim S, Dale BE (2004) Global potential bioethanol production from wasted crops and crop residues. Biomass Bioenergy 26:361-375

Kumar SA, Pushpa A (2012) Microbial pretreatment of lignocellulosics materials and production of bioethanol. J Environ Res Dev 7:375-380

Kumar P, Barrett DM, Delwiche MJ, Stroeve P (2009) Methods for pretreatment of lignocellulosic biomass for efficient hydrolysis and biofuel production. Ind Eng Chem Res 48:3713-3729

Liu J, Yang J (2007) Cellulase production by Trichoderma koningii AS34262 in solid state fermentation using lignocellulosic waste from the vinegar industry. Food Technol Biotechnol 45:420-425

Mandels M (1975) Microbial source of cellulose. Biotechnol Bioeng 5:81-105
Mandels M, Sternburg D (1976) Recent advances in cellular technology. J Ferment Technol 54:267-286

Mandels M, Hontz L, Nystrom J (1974) Enzymatic hydrolysis of waste cellulose. Biotechnol Bioeng 16:1471-1493

Melo IR, Pimentel MF, Lopes CE, Calazan GMT (2007) Application of fractional factorial design to levan production by Zymomonas mobilis. Braz J Microbiol 38:45-51

Milala MA, Shugaba A, Gidado A, Ene AC, Wafar JA (2005) Studies on the use of agricultural wastes for cellulase enzyme production by Aspergillus niger. Res J Agric Biol Sci 1:325-328

Miller GL (1959) Use of dinitrosalicylic acid reagent for determination of reducing sugar. Anal Chem 31:426-428

Mrudula S, Murugammal R (2011) Production of cellulase by Aspergillus niger under submerged and solid state fermentation using coir waste as a substrate. Braz J Microbiol 42:1119-1127

Murad HA, Azzaz HEH (2013) Cellulase production from rice straw by Aspergillus flavus NRRL 5521. Sci Int 1:103-107

Nanda S, Mohammad J, Reddy SN, Kozinski JA, Dalai AK (2014) Pathways of lignocellulosic biomass conversion to renewable fuels. Biomass Convers Biorefin 4:157-191

Narasimha G, Sridevi A, Viswanath B, Chandra SM, Reddy RB (2006) Nutrient effects on production of cellulolytic enzymes by Aspergillus niger. Afr J Biotechnol 5:472-476

Nazir A, Soni R, Saini HS, Kaur A, Chadha BS (2010) Profiling differential expression of cellulases and metabolite footprints in Aspergillus terreus. Appl Biochem Biotechnol 162:538-547

Niranjane AP, Madhou P, Stevenson TW (2007) The effect of carbohydrate carbon sources on the production of cellulase by Phlebia gigantean. Enz Microb Technol 40:1464-1468

Omojasola PF, Jilani OP (2009) Cellulase production by Trichoderma longi, Aspergillus niger and Saccharomyces cerevisae cultured on plantain peel. Res J Microbiol 4:67-74

Panagiotou G, Kekos D, Macris BJ, Christakopoulos P (2003) Production of cellulolytic and xylanolytic enzymes by Fusarium oxysporum grown on corn stover in solid state fermentation. Ind Crops Prod 18:37-45

Park J, Kanda E, Fukushima A, Motobayashi K, Nagata K, Kondo M, Oshita Y, Morita S, Tokuyasu K (2011) Contents of various sources of glucose and fructose in rice straw, a potential feedstock for ethanol production in Japan. Biomass Bioenergy 35:3733-3735

Pothiraj C, Balaji P, Eyini M (2006) Enhanced production of cellulases by various fungal cultures in solid state fermentation of cassava waste. AfrJ Biotechnol 5:1882-1885

Ramos LP, Beruil C, Saddler JN (1993) The use of enzyme recycling and the influence of sugar accumulation on the cellulose hydrolysis by Trichoderma cellulases. Enzyme Microb Technol 15:19-25

Rodriguez IA, Escobedo CP, Paramo MGZ, Romero EL, Camacho HCC (2005) Degradation of cellulose by the bean-pathogenic fungus Colletotrichum lindemuthianum. Production of extracellular cellulolytic enzymes by cellulose induction. Antonie van Leeuwenhock 87:301-310

Rahnama N, Foo HL, Rahman NAA, Ariff A, Md Shah UK (2014) Saccharification of rice straw by cellulase from a local Trichoderma harzianum SNRS3 for biobutanol production. BMC Biotechnol 14:1-12

Sadhu S, Maiti TK (2013) Cellulase production by bacteria: a review. Br Microbiol Res J 3:235-258

Saha BC (2004) Production purification and properties of endoglucanase from a newly isolated strain of Mucor circinelloides. Proc Biochem 39:1871-1876

Salehi SMA, Karimi K, Behzad T, Poornejad N (2012) Efficient conversion of rice straw to bioethanol using sodium carbonate pretreatment. Energy Fuels 26:7354-7361 
Sharma N, Bhalla TC, Bhatt AK (1991) Partial purification and characterization of extracellular cellulase from strain of Trichoderma viride isolated from forest soil. Folia Microbiol 36:353-356

Sherief AA, El-Naggar NE, Hamza SS (2010) Bioprocessing of lignocellulosic waste for production of bioethanol using thermotolerant Aspergillus fumigatus under solid state fermentation conditions. J Biotechnol 9:513-522

Singh A, Singh N, Bishnoi NR (2009) Production of cellulases by Aspergillus heteromorphus from wheat straw under submerged fermentation. Int J Civ Environ Eng 1:23-26

Singh R, Srivastava M, Shukla A (2016) Environmental sustainability of bioethanol production from rice straw in India: a review. Renew Sustain Energy Rev 54:202-216

Singhania RR, Sukumaran RK, Pillai A, Prema P, Szakacs G, Pandey A (2006) Solid-state fermentation of lignocellulosic substrates for cellulase production by Trichoderma reesei NRRL 11460 . Ind J Biotechnol 5:332-336

Smith PJ, Rinzema A, Tramper J, Schlosser EE, Knol W (1996) Accurate determination of process variables in a solid-state fermentation system. Proc Biochem 31:669-678

Sohail M, Siddiqi R, Ahmad A, Khan SA (2009) Cellulase production from Aspergillus niger MS82: effect of temperature and $\mathrm{pH}$. New Biotechnol 25:437-441
Sukumaran RK, Singhania RR, Mathew GM, Pandey A (2009) Cellulase production using biomass feedstock and its application in lignocellulosic saccharification for bioethanol production. Renew Energy 34:421-424

Tong CC, Rajendra K (1992) Effect or carbon and nitrogen sources on the growth and production of cellulase enzymes of a newly isolated Aspergillus sp. Pertanika 15:40-45

$\mathrm{Vu}$ VH, Pham TA, Kim K (2010) Improvement of a fungal strain by repeated and sequential mutagenesis and optimization of solidstate fermentation for the hyper-production of raw starchdigesting enzyme. J Microbiol Biotechnol 20:718-726

$\mathrm{Vu}$ VH, Pham TA, Kim K (2011) Improvement of fungal cellulase production by mutation and optimization of solid state fermentation. Mycobiol 39:20-25

Vyas A, Vyas D, Vyas KM (2005) Production and optimization of cellulases on pretreated groundnut shell by Aspergillus terreus AV49. J Sci Ind Res 64:281-286

Wati L, Kumari S, Kundu BS (2007) Paddy straw as substrate for ethanol production. Ind J Microbiol 47:26-29

Wilson DB (2011) Microbial diversity of cellulose hydrolysis. Curr Opin Microbiol 14:1-5

Xiong H, Weymarn NV, Leisola M, Turunen O (2004) Influence of $\mathrm{pH}$ on the production of xylanase by Trichoderma reesei Rut C-30. Proc Biochem 39:729-733 